\title{
Correction to: Effect of Obesity on Asthma Severity in Urban School Children of Kanpur, India: An Analytical Cross-Sectional Study
}

\section{S. P. Senthil Kumar ${ }^{1}$ (D) Shalu Jain ${ }^{2}$}

Published online: 27 August 2020

○) Springer Science+Business Media, LLC, part of Springer Nature 2020

\section{Correction to: Journal of Community Health (2020) 45:342-347 https://doi.org/10.1007/s10900-019-00749-z}

The original publication of the article [1] unfortunately contain mistakes. The quotations from various sources [2-6] in the Discussion section should have been embraced by quotation marks.

\section{References}

1. Senthil Kumar, S. P., \& Jain, S. (2020). Effect of obesity on asthma severity in urban school children of Kanpur, India: An analytical cross-sectional study. Journal of Community Health, 45, 342-347.

2. El Helaly, N., Kamel, Y., Abd Elaziz, E., Elwan, A., \& Nabih, M. (2009). Childhoold obesity and asthma severity Is there a link? Journal of Biological Sciences, 9(3), 259-263.

3. Tantisira, K. G., Litonjua, A. A., Weiss, S. T., \& Fuhlbrigge, A. L. (2003). Association of body mass with pulmonary function in the Childhood Asthma Management Program (CAMP). Thorax, 58, 1036-1041.

4. Shore, S. A., \& Fredberg, J. J. (2005). Obesity, smooth muscle and airway hyper responsiveness. The Journal of Allergy and Clinical Immunology, 115, 925-927.

5. Schachter, L. M., Salome, C. M., Peat, J. K., \& Woolcock, A. J. (2001). Obesity is a risk for asthma and wheeze but not airway hyperresponsiveness. Thorax, 56, 4-8.

6. Gold, D. R., Damokosh, A. I., Dockery, D. W., \& Berkey, C. S. (2003). Body-mass index as a predictor of incident asthma in

The original article can be found online at https://doi.org/10.1007/ s10900-019-00749-z.

S. P. Senthil Kumar

drsenthilsp@yahoo.co.in

Shalu Jain

shalusen09@yahoo.co.in

1 Columbia Asia Hospital, Whitefield, Bengaluru, Karnataka, India

2 Femiint Health Care, Whitefield, Bengaluru, Karnataka, India a prospective cohort of children. Pediatric Pulmonology, 36(6), 514-521.

Publisher's Note Springer Nature remains neutral with regard to jurisdictional claims in published maps and institutional affiliations. 